\title{
Systematic review and meta-analysis for the biotechnological production of THC in Morocco
} \author{
Amri $^{6}$ \\ ${ }^{1}$ Research Laboratory Innovation \& Information System, EuRSED Vienne France. \\ ${ }^{2}$ UIT, University Ibn Tofa1l, Kenitra Morocco \\ ${ }^{3}$ PHI, Pharmaceutical Institut, Ain El Aouda Morocco \\ ${ }^{4}$ UIT, University Ibn Tofall, Kenitra Morocco \\ ${ }^{5}$ CNRST, Center for Scientific and Technical Research, Rabat Morocco \\ ${ }^{6}$ IAGGR, Institute of Genetic Analysis in the Royal Gendarmerie, Rabat Morocco
}

Fadwa badrana ${ }^{1,6^{*}}$, Abdelrhani mokhtari ${ }^{2}$, Najete safini $^{3}$, Abdelmajid soulaymani ${ }^{4}$,Elmostafa el fahime ${ }^{5}$,and Hamid el

\begin{abstract}
Cannabinoids have promising therapeutic potential. $\Delta 9$-tetrahydrocannabinol (THC), the most important psychotropic active ingredient of Cannabis Sativa $L$, has been the subject of several chemical, pharmacological and biosynthetic studies. In this context, a meta-analysis of biotechnological processes applied to the production of recombinant cannabinoid THC worldwide was carried out. The objective was to highlight the potential of these processes on the Moroccan variety of Cannabis Sativa. The PubMed, ScienceDirect and Web of Science search motors were used to search for original scientific work presenting biotechnological tools used in the production of THC. The scientific articles exploited are those published before the end of 2020. Succinct analysis of the experimental work performed showed that expression of the gene encoding Cannabis Sativa L. THCA synthase was performed on prokaryotic and eukaryotic expression systems. Currently, no functional expression could be obtained in E. coli. Whereas, production of recombinant protein (THCA Synthase) associated with significant enzymatic activity was obtained in P. pastoris cultures (F. Saccharomycetaceae). The exploitation of the sequences showed the presence of a large similarity between the THCA Synthase gene of cannabis Sativa of the Moroccan variety and the mRNA precursor of the same gene reported in several studies. This will allow us to use a specific signal sequence of choice for an adopted expression host, in order to produce the recombinant THCA synthase enzyme from the Moroccan Cannabis Sativa $L$ strain on $P$. pastoris cultures.
\end{abstract}

\section{Introduction}

Cannabis, Native to Central Asia, is a plant apparent to the Cannabaceae family, is one of the oldest psychotropic drugs known to humanity. The name of the plant Cannabis is derived from a Scythian or Thracian word, which was lent to the Persian language as kanab, then to the Greek as

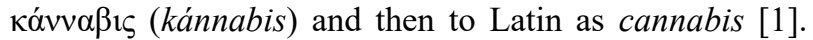
According to archaeological findings, it was cultivated long before the appearance of writing.

It is not easy to objectively trace the exact history of cannabis use. However, it was agreed that the first use of cannabis (cultivation and consumption) dates back to the Neolithic area since $4000 \mathrm{BC}$ according to recent archaeological findings in China [2]. Later, some historical resources are consistent with the fact that the Emperor of China, Shên-nung 2000 BC, discoverer of tea and ephedrine, was the first to describe the psychotropic properties in his collection of Chinese medicinal herbs
'Pen-ts'ao Ching'. It has been used as a hallucinogen for ritual practices, analgesics for therapeutic virtues and as anesthetic in surgical operations [3]. It then spread to India from China [4].

In the 19th century, the exploitation of the plant has widely diversified and its use has exceeded its traditional consumption to take an industrial and pharmaceutical dimension. Thus, it is cultivated for its fibers, its seeds, its recreational consumption and its medicinal use. The pharmacological properties are gradually revealed, the British doctor, William O'Shaughness, working in India in 1839 discovered the antiemetic, appetite stimulating, analgesic, muscle relaxing and anticonvulsant properties of cannabis [5]. It was recommended to Queen Victoria to relieve dysmenorrhea in the form of an herbal tea [6]

The introduction of cannabis into the public health domain is gradually expanding. For example, cannabis was listed in 1854 in dispensaries in the United States [7]. It has been sold freely in pharmacies in Western countries

* Corresponding author: fadwa.badrana@uit.ac.ma 
and available in the British pharmacopoeia in extract and tincture form for over 100 years [8].

At the beginning of the 20th century, the effects of the use of cannabis without limitation created social scourges: insanity, moral and intellectual deterioration, violence and various crimes. For example, in the United States of America, the authorities authorized alcohol and condemned the use of cannabis by removing it from the pharmacopoeia. Britain and most European countries have taken the same step in banning cannabis. These countries subsequently adopted the 1971 United Nations Convention on Psychotropic Substances [9]. This Convention, established by the United Nations Office on Drugs and Crime (UNODC).

In Morocco, the first established cannabis crops are imprecise, some say that cannabis cultivation dates back to the Arab-Muslim conquest of the Greater Maghreb around 680 A.D. when the Umayyad caliphate, under the direction of its general Uqba ibn Nafi, conquered most of North Africa [10]. Others attributed it to the incursions of the Portuguese Christians of the sixteenth century and the French and Spanish Christian protectorates that began in the early twentieth century. Nevertheless, historians agree on the existence of cannabis cultivation in the Kétama region of the Central Rif in the fifteenth century [11].

The development of the first legal texts began in 1932 following the prohibition of cannabis production in Morocco by the dahir of 22 December. Morocco under the French protectorate had prohibited the production, trafficking and cultivation of cannabis, with the exception of that cultivated, under the control of the Régie, in Haouz (plain of the Marrakech region) and Gharb (plain of the Kenitra region) [13].

Subsequently, King Mohammed V confirmed the prohibition by the dahir of 24 April 1954 and extended the prohibition of cannabis cultivation and consumption to all of Morocco under the ex-Spanish protectorate, including the northern areas [12].

Cannabis cultivation has also benefited from the agronomic development of the 2000s in Morocco, notably the selection of high-yielding varieties, the improvement of production techniques: Agricultural nursery seedbed, specific soil preparation, row planting, drip irrigation, mulching and improved harvesting technique, the introduction of feminized seed varieties and the professionalization of the hashish industry, which confirms its position as a world leader in hashish production [14] [15].

In January 2019, the World Health Organization (WHO) issued recommendations on cannabis and its derivatives, following which, the United Nations Commission on Narcotic Drugs (CND), met on 02 December 2020 in Vienna (Austria), and decided to remove cannabis from Table IV of the Single Convention on Narcotic Drugs of 1961. The member states of the United Nations Commission on Narcotic Drugs, including Morocco, agreed to remove cannabis from the category of the most dangerous drugs.

The Moroccan legal arsenal is already equipped with a law that allows the cultivation of cannabis for scientific purposes, with permission from the Ministry of Health. However, the recent ratification by Morocco of the UN
Convention established by the United Nations Commission on Narcotic Drugs (CND) opens the way to the establishment of a legal framework for the therapeutic and industrial use of cannabis in Morocco, without taking the step of decriminalization. Thus, the Moroccan government adopted the project of law no 13.21 on March 11,2021 on the legitimate uses and aspects related to the therapeutic use and scientific research of Indian cannabis.

Cannabinoids extracted from cannabis, which are found only in this plant, are secondary metabolites consisting of alkylresorcinol and monoterpene groups. Currently, more than 60 cannabinoids have been isolated from marijuana or fresh Cannabis leaves, and their pharmacological properties have been extensively studied [16]. Among them is $\Delta$-9-tetrahydrocannabinol (THC), the psychoactive component of marijuana [17]. THC is a chemical derivative artificially from the cannabinoid $\Delta-9$ tetrahydrocannabinolic acid (THCA), formed by nonenzymatic decarboxylation during storage and smoking, THCA accumulates in fresh leaves of C. sativa [18][19]. THCA is biosynthesized from cannabigerolic acid (CBGA) by the oxidoreductase THCA synthase in rapidly expanding leaves of C. sativa [20]. This enzyme oxidatively cyclizes the monoterpene portion of CBGA to form THCA (Figure 1) [21]. The activity of this enzyme was not detected in a non-psychoactive fiber-type strain of Cannabis, which contains cannabidiolic acid as the major cannabinoid and only a trace amount of THCA, indicating that THCA synthase is an important enzyme controlling the psychoactivity of Cannabis Sativa. [22] (Taura et al. 1996). In addition, the complete coding region of the THCA synthase gene, GenBank accession number gene (JQ437481-JQ437488), was sequenced from DNA extracted from Moroccan cannabis resin [23].

Since the discovery of the human endocannabinoid system in 1980, the effects and potential pharmaceutical applications of THC have been widely studied. This cannabinoid exerts various therapeutic activities such as nausea relief caused by cancer chemotherapy [24], suppression of muscle spasticity and analgesics for pain associated with multiple sclerosis, epilepsy, glaucoma, Tourette's syndrome and damage of the spinal cord. [25][9]. Other applications are still being studied and the demand for pharmaceutical grade THC continues to grow [26][27].

As, Cannabinoids have interesting therapeutic potential as antiemetics, appetite stimulants in debilitating diseases and analgesics. THC has attracted much attention, various chemical, pharmacological and biosynthetic studies have been conducted on this cannabinoid [28][29]. However, legal regulations for the cultivation of $\mathrm{C}$. sativa in most countries, low yielding chemical syntheses of THC or expensive chiral precursors are disadvantages for a profitable production of THC [28][30]. Therefore, a biotechnological approach of transferring enzymes from the plant biosynthetic pathway of $\Delta$ 9-tetrahydrocannabinolic acid (THCA), the precursor of THC, into a microbial production host could be a suitable alternative. This pushes the scientific community to perform more studies for cost-effective production of the main psychoactive component of cannabis which is $\Delta$ 9-tetrahydrocannabinol, commonly known as THC. In 
this analysis we have focused on applications that have been carried out for the purpose of THCA production in a whole cell THCAS production system. Thus, the possibility of carrying out these studies for Moroccan cannabis.

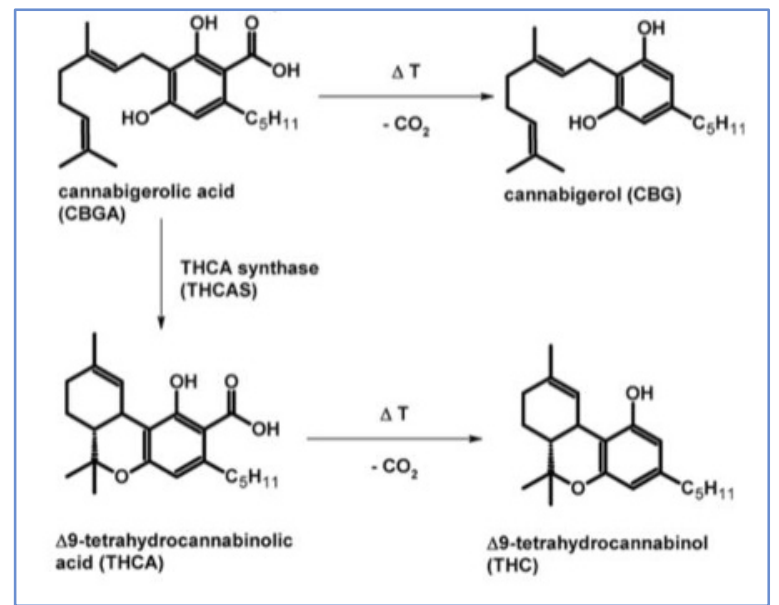

Fig.1 la biosynthese du $\Delta$-1-tétrahydrocannabinol THC à partir de l'acide cannabigérolique CBGA [31].

\section{Methodology}

A systematic search was conducted in PubMed, ScienceDirect, and Web of Science by the end of 2020. The keywords used were Cannabis sativa, marijuana, hashish, hashich, haschich, cannabinoid, tetrahydrocannabinol, THC, tetrahydrocannabinolic acid synthase, THCAS, biosynthesis, biotechnology, Morocco.

After the initial screening, all articles and reviews, including biotechnology protocols or literature evaluating potential therapeutic applications of cannabinoids, were read. For the final selection, only relevant articles were retained. Therefore, open-label studies were excluded. The reference list of all matching articles was also reviewed to include all related articles and journals. The search focused on work and data available in English and French. This study was conducted in accordance with the PRISMA (Preferred Reporting Items for Systematic Reviews and Meta-Analyses) standards

For each biotechnology research, the country where the project took place, the type of study and comparisons performed, the products and doses used, their efficacy and drawbacks were identified. Also, the efficiency and disadvantage of each production method. In addition, the comparison between the THCAS gene of the Moroccan cannabis sativa variety and the already sequenced cDNA was performed.

\section{Result}

\subsection{Biotechnology assays:}

\subsubsection{Overexpression of tetrahydrocannabinolic acid synthase (thcas) in tobacco hairy root cultures and insect cells:}

THCAS is the first cloned gene involved in cannabinoid biosynthesis while early attempts to synthesize THCAS at the level of E.coli bacteria resulted in the accumulation of insoluble and non-functional protein.

The cloning and expression of the THCAS gene was initially performed in the tobacco plant. Thus, the pBI121 vector with the $35 \mathrm{~S}$ promoter of cauliflower mosaic virus and the THCAS gene was introduced into the tobacco genome (N. taba- cum cv Xanthi).

The tobacco plant infected with the bacterium Agrobacterium rhizogenes carrying the viral vector showed the appearance of transformants characterized by hairy roots and rapid growth in its stems. This phenotypic expression is explained by the insertion of the bacterial gene responsible for root formation. It was confirmed that the transformed tobacco plant possesses THCA synthase activity in hairy roots (1.16 picokatal/mg THCAS protein) and in shoots $(0.27 \mathrm{picokatal} / \mathrm{mg}$ THCAS protein $)$. In addition, it was investigated, whether the transformed tobacco can produce THCA. When transgenic hairy roots were grown in liquid B5 medium $(30 \mathrm{ml})$ supplemented with $1 \mathrm{mg}$ CBGA, the maximum level of THCA was produced 2 days after addition of the substrate $(82 \mathrm{ug}$, 8.2\% CBGA conversion).

The rate of THCA production was increased by overexpression of the THCAS enzyme in a baculovirusinsect cell system. After, insect cells (Sf9) were infected with baculoviruses harboring the vector ( $\mathrm{pFastBac1)}$ that integrates the THCAS gene, THCA synthase activity was measured in the culture medium (10.5 picokatal $/ \mathrm{mg}$ THCAS protein) and in the cell extract ( 0.1 picokatal $/ \mathrm{mg}$ THCAS protein) respectively. Thus, it was found that most of the recombinant enzyme was secreted outside the cells (Table 1).

\subsubsection{Overexpression of tetrahydrocannabinolic acid synthase in yeast cultures:}

P. pastoris cells were transformed with the pPICZ B vector harboring the THCAS gene under the control of the AOX1 promoter [31].The coding region of the THCA synthase gene was introduced into the genome of the Pichia pastoris SMD1168 h strain deficient in proteinase $\mathrm{A}$ and frequently used for heterologous expression. THCAS activity levels in cell extract and culture medium were measured. The activity in the medium (31.7 pkat/l) was much higher than that in the cells (1.84 pkat/l).

Based on these results, Zirpel, 2015 investigated the expression of THCAS in P. pastoris, Saccharomyces cerevisiae and E. coli. Thus, to achieve functional expression in a prokaryotic system. E. coli SHuffle T7 Express and SHuffle T7 Express lysY cells, capable of establishing disulfide bonds in the cytosol, were transformed with the pET28a $(+)$ THCAS vector harboring the THCAS cDNA without a signal peptide. In an effort to eliminate solubility issues during expression, cells were also transformed with the pET32a (+) _THCAS vector containing an additional thioredoxin fusion tag for 
improved solubility. Contrary to expectations, no THCAS activity was observed in eukaryotic E. coli cells. Furthermore, to avoid secretion of the enzyme from yeast cells, THCAS was targeted to the yeast vacuole using a vacuolar signal peptide. Since vacuolar proteases can degrade THCAS, wild type and protease-deficient strains were compared to each other. Thus, the PEP4 gene was eliminated by homologous recombination in $\mathrm{S}$. cerevisiae CEN.PK2-1C Dgal1 (wt). PichiaPink strains 1 (wt), 2

Table 1 : Recombinant THCAS expression result comparison

\begin{tabular}{|c|c|c|c|c|c|c|}
\hline Study & Paid & $\begin{array}{l}\text { Cloning host } \\
\text { subcloning }\end{array}$ & Vector & Host of expression & $\begin{array}{c}\text { Enzymatic activity of } \\
\text { THCAS }\end{array}$ & $\begin{array}{l}\text { Quantity } \\
\text { produced }\end{array}$ \\
\hline \multirow{3}{*}{$\begin{array}{l}\text { Sirikant } \\
\text { aramas } \\
2004\end{array}$} & \multirow{3}{*}{ Japan } & $\begin{array}{l}\text {-Unspecified } \\
\text { bacteria. }\end{array}$ & not specified & -Same bacteria. & -Absence of activity. & - \\
\hline & & $\begin{array}{c}\text { - Souche } \\
15834 \\
\text { d'Agrobacteri } \\
\text { um } \\
\text { rhizogenes. } \\
\end{array}$ & $\begin{array}{c}-\mathrm{pBI} 121 \\
-35 \mathrm{~S} \text { promoter of } \\
\text { cauliflower mosaic } \\
\text { virus. }\end{array}$ & $\begin{array}{c}\text {-Tobacco stem }(\mathrm{N} . \\
\text { taba- cum cv } \\
\text { Xanthi }\end{array}$ & $\begin{array}{c}\text {-Hairy roots (1.16 } \\
\text { picokatal/mg protein) } \\
\text { and shoots }(0.27 \\
\text { picokatal/mg protein } \\
\text { THCAS) }\end{array}$ & $\begin{array}{c}\text {-For } 1 \mathrm{mg} \text { of } \\
\text { CBGA, } 82 \mathrm{ug} \\
\text { of THCA is } \\
\text { produced. }\end{array}$ \\
\hline & & $\begin{array}{l}\text { E. coli } \\
\text { DH10Bac } \\
\text { bacmid }\end{array}$ & - pFastBac1. & $\begin{array}{l}\text {-Spodoptera } \\
\text { frugiperda }(\mathrm{Sf} 9) \\
\text { insect cells }\end{array}$ & $\begin{array}{c}\text {-In culture medium } \\
\text { (10.5 picokatal/mg } \\
\text { protein) } \\
\text {-In cell extract }(0.1 \\
\text { picokatal/mg protein) }\end{array}$ & $\begin{array}{l}\text {-More than } 1 \\
\text { mg THCAS } \\
\text { for a } 1 \text { litre } \\
\text { culture. }\end{array}$ \\
\hline $\begin{array}{l}\text { Taura } \\
2007\end{array}$ & Japan & $\begin{array}{c}\text { not } \\
\text { specified }\end{array}$ & $\begin{array}{c}\text {-pPICZ B } \\
\text { AOX1 promoter }\end{array}$ & $\begin{array}{l}\text {-Pichia pastoris } \\
\text { SMD1168h } \\
\text { proteinase A } \\
\text { deficient }\end{array}$ & $\begin{array}{c}\text {-Activity in the } \\
\text { medium ( } 31.7 \text { pkat/l); } \\
\text {-Activity in the cells } \\
(1.84 \text { pkat/l); } \\
\text {-After optimisation: } \\
\text { The activity in the } \\
\text { medium became } 1.32 \\
\text { nkat/l. }\end{array}$ & $\begin{array}{l}-32.6 \mathrm{mg} \text { per } \\
\text { litre of the } \\
\text { supernatant. }\end{array}$ \\
\hline \multirow[b]{2}{*}{$\begin{array}{c}\text { Zirpel } \\
2015\end{array}$} & \multirow[b]{2}{*}{ Germany } & $\begin{array}{c}\text { not } \\
\text { specified }\end{array}$ & $\begin{array}{c}\text {-pET28a }(+) \\
\text {-pET32a }(+) \text { contenant } \\
\text { un marqueur de fusion } \\
\text { de thiorédoxine. } \\
\text {-Ces deux vecteurs } \\
\text { contiennentt un } \\
\text { cDNA of THCAS } \\
\text { sans séquence signal }\end{array}$ & $\begin{array}{l}\text {-E. coli SHuffle T7 } \\
\text { Express ; } \\
\text { - E. coli SHuffle T7 } \\
\text { Express lysY. }\end{array}$ & $\begin{array}{l}\text { Inactive and insoluble } \\
\text { protein. }\end{array}$ & not specified \\
\hline & & not specified & $\begin{array}{c}\text { - pDionysos_with a } \\
\text { cDNA of the THCAS } \\
\text { codon (5'UTR N- } \\
\text { terminal (AAAAAA } \\
\text { followed by a } \\
\text { sequence encoding } \\
\text { the } 24 \text { aa signal } \\
\text { peptide of proteinase } \\
\text { A (Uniprot P07267); } \\
\text { C-terminal sequence } \\
\text { encoding } 3 \text { additional } \\
\text { histidines) }\end{array}$ & $\begin{array}{c}\text {-Saccharomyces } \\
\text { cerevisiae } \\
\text { CEN.PK2-1C } \Delta \\
\text { gal1 (deficient in } \beta \text { - } \\
\text { galactokinase); } \\
\text {-Saccharomyces } \\
\text { cerevisiae } \\
\text { CEN.PK2-1C } \Delta \\
\text { gall } \Delta \text { pep4 } \\
\text { (deficient in } \beta \text { - } \\
\text { galactokinase and } \\
\text { vacuolar Proteinase } \\
\text { A). }\end{array}$ & $\begin{array}{l}\text {-Specific activity } \\
\text { intracellular } 5.6 \pm 0.3 \\
\quad\left(\text { pkat } \mathrm{g}_{\mathrm{CDW}}-1\right)\end{array}$ & not specified \\
\hline
\end{tabular}

(pep4) and 3 (prb1) were chosen for transformation with high and low copy vectors (HC and LC) for genome integration. Both transgenic yeast expression systems expressed THCAS, with the highest enzyme activity in P. pastoris. The proteinase A-deficient strain transformed with the high-copy vector (PP2 HC) had the highest THCAS activity between P. pastoris and S. cerevisiae strains (Table 1). 


\begin{tabular}{|c|c|c|c|c|c|c|}
\hline & & not specified & $\begin{array}{l}\text { - pPink-HC and } \\
\text { pPink-LC with } \\
\text { THCAS codon cDNA } \\
\text { (N-terminal 5'UTR } \\
\text { (AAAAAA) followed } \\
\text { by a sequence } \\
\text { encoding } 24 \text { aa } \\
\text { proteinase A signal } \\
\text { peptide (Uniprot } \\
\text { F2QUG8); C-terminal } \\
\text { sequence encoding } 3 \\
\text { additional histidines) }\end{array}$ & $\begin{array}{c}\text {-Pichia pastoris } \\
\text { PichiaPink1 ade2 } \\
\text {-Pichia pastoris } \\
\text { PichiaPink2 ade2, } \\
\text { pep4 ; } \\
\text {-Pichia pastoris } \\
\text { PichiaPink2 ade2, } \\
\text { prb1 ; }\end{array}$ & $\begin{array}{c}\text {-Intracellular specific } \\
\text { activity } 98 \pm 5 \text { (pkat } \\
\text { ml-1) } \\
\text {-Extracellular specific } \\
\text { activity } 44 \pm 4 \text { (pkat } \\
\text { ml-1) }\end{array}$ & $\begin{array}{c}-0,36 \mathrm{~g} \\
\left.\mathrm{THCA}^{-1}\right) \mathrm{de} \\
\text { THCA }\end{array}$ \\
\hline \multirow{2}{*}{$\begin{array}{l}\text { Lange } \\
2015\end{array}$} & \multirow[b]{2}{*}{ Germany } & $\begin{array}{c}\text {-Escherichia } \\
\text { coli BL21 } \\
\text { (DE3) }\end{array}$ & -pET15b- & -Same bacteria. & -Insoluble protein. & \\
\hline & & not specified & -pPICZA & $\begin{array}{c}\text { P. pastoris KM71 } \\
\text { KE1 }\end{array}$ & $\begin{array}{c}-\sim 5-10 \mathrm{mg} \text { de } \\
\text { THCAS } 1-1 \\
-121.5 \mathrm{U} \mathrm{g}^{-1} \text { THCAS } \\
\end{array}$ & $\begin{array}{c}\text {-À l'echelle } \\
\text { de quelque } \\
\text { mg en THCA } \\
1^{-1} \\
\end{array}$ \\
\hline $\begin{array}{l}\text { Zirpel } \\
2018\end{array}$ & Germany & not specified & not specified & $\begin{array}{l}\text { Komagataella } \\
\text { phaffii (formerly } \\
\text { Pichia pastoris) }\end{array}$ & not specified & $\begin{aligned} 3,05 \mathrm{~g} \\
\text { THCA L }^{-1}\end{aligned}$ \\
\hline $\begin{array}{l}\text { Geissler } \\
2018\end{array}$ & Germany & $\begin{array}{c}\text {-Escherichia } \\
\text { coli TOP10 } \\
\text { cells } \\
\text {-Agrobac- } \\
\text { terium } \\
\text { tumefaciens } \\
\text { strain } \\
\text { EHA105 } \\
\end{array}$ & not specified & $\begin{array}{c}\text {-Nicotiana } \\
\text { benthamiana }\end{array}$ & $\begin{array}{l}123 \pm 12 \text { fkat } \mathrm{g}^{-1} \\
\text { activity }\end{array}$ & not specified \\
\hline $\begin{array}{c}\text { Luo } \\
2019\end{array}$ & USA & $\begin{array}{l}\text { Escherichia } \\
\text { coli BL21 } \\
\text { (DE3) }\end{array}$ & not specified & $\begin{array}{c}\text { - Saccharomyces } \\
\text { cerevisiae } \\
\text { CEN.PK2-1C }\end{array}$ & not specified & $\begin{array}{c}8 \mathrm{mg} \mathrm{l}^{-1} \text { de } \\
\text { THCA }\end{array}$ \\
\hline
\end{tabular}

\subsection{Alignment of the nucleotide sequence of the Moroccan THCAS gene with that of its mRNA precursor:}

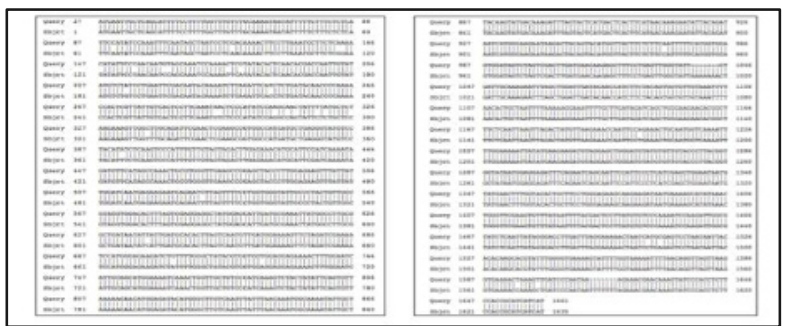

Fig.2 Alignement entre deux séquences de nucléotides. query (référence) : ARNm de Cannabis sativa précurseur de l'acide tétrahydrocannabinolique synthase (AB057805.1) Correspond à 1885 nucléotides. Sbjct (Sujet): Gène de l'acide tétrahydrocannabinolique synthase du l'isolat 01 de la résine du Cannabis Sativa marocain (JQ437481.1) Correspond à 1635 nucléotides.

Alignment between the two sequences was performed to compare the Moroccan-derived THCAS gene [32] with its previously sequenced cDNA homologue [33]. The alignment is $98 \%(1603 / 1635)$ from the ATG star codon to the last three CAT (Histidine) codons of the THCAS gene (JQ437481.1) (Figure 2).

\subsection{Analysis of the sequence of the THCAS protein derived from:}

1 MNCSAFSFWF VCKIIPFFLS PNIQISIANP QENFLKCFSE YIPNNPANPK FIYTQHDQLY 61 MSVLNSTIQN LRFTSDTTPK PLVIVTPSNV SHIQASILCS KKVGLQIRTR SGGHDABGMS 121 YISQVPFVVV DLRNMHSIKI DVHSQTAWVE AGATLGBVYY WINEKNBNFS PPGGYCPTVG 181 VGGEFSGGGY GALMRNYGLA ADNIIDAHLV NVDGKVLDRK SYGEDLFWAI RGGGGENFGI 241 IAAWRIRLVA VPSKSTIPSV KKNMBIHGLV KLFNKWONIA YKYDRDLVLM THFITKNITD 241 IAAWKIKLVA VPSKSTIFSV KKNMBIHGLV KLFNKWQNIA YKYDKDLVLM THFITKNITD

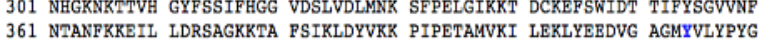
361 NTANFKKEIL LDRSAGKKTA PSIKLDYVKK PIPETAMVKI LEKLYEBDVG AGMYLYPYC 481 YLNYRDLDLG KTNPESPNNY TQARIWGEKY FGKNFNRLVK VKTKADPNNP PRNEQSIPPI 541 PPHHH

Fig.3 La séquence proteique tetrahydrocannabinolic acid synthase (GenBank accession number AFI24245.1); H: His114; C: Cys176; H: His292; Y: Tyr417; Y: Tyr484.

THCA synthase is a flavoprotein since the presence of coenzyme FAD is essential for its enzyme activity [33]. It covalently binds to THCAS His114 and Cys176. Tyr484 is the catalytic site of the THCAS enzyme and residues His292 and Tyr417 are involved in binding to the CBGA substrate [34]. The presence of these amino acids was investigated in the GenBank accession number (AFI24245.1) protein sequence corresponding to the THCAS GenBank accession number (JQ437481.1) gene. These sites, which are critical to the enzymatic activity of THCAS, were found to be present at the same locations as described above (Figure 3)

NH2-terminale was identified as NPRENFLKXFSKHIPNNVANPKLV [35]. This sequence corresponds to the nucleotide sequence 85-156 Ns with 9 nucleotide mismatches. This difference results in NH2-terminal (AFI24245.1) NPQENFLKCEFSEYIPNNPANPKEI with 7 discordant amino acids. 


\subsection{Word Cloud Analysis:}

As a research tool, a word cloud is a visual representation of the repetition of words derived from a written text, to identify the subject of a written document: the more often the word appears in the analysed passage, the larger it is in the generated image, the size of the words reflects the frequency of use. However, word clouds have a number of limitations. However, the tool fails to group words that have the same or similar meaning. A limit of 100 words has been set and common words have been removed. The most frequent words for the selected references in the expression analysis are THCA Synthase and Pichia pasteri. And for. The most frequent word for the selected global references is the word cannabis (figure 4).

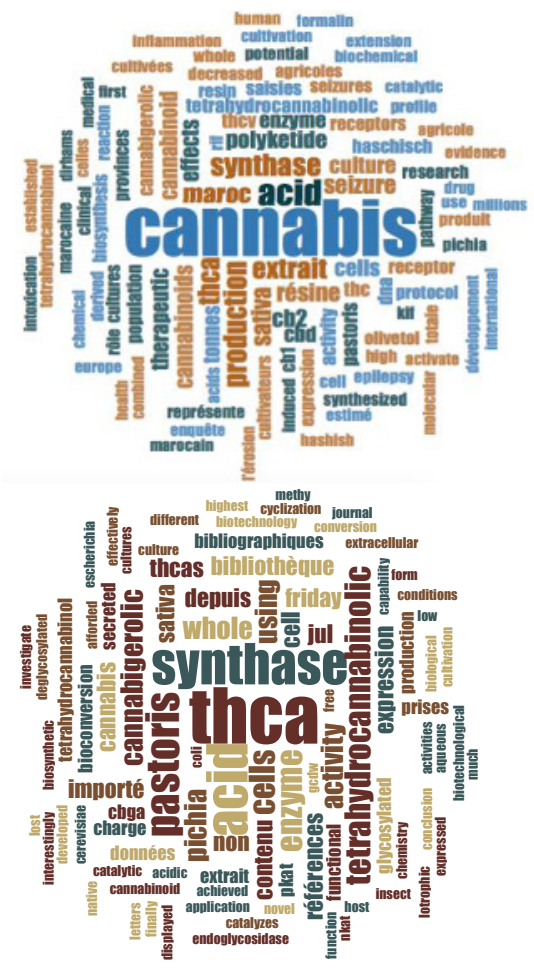

Fig.4 Qualitative analysis (word cloud) by Nvivo $10 \AA$ software; a: word cloud at the top of the references used for the study of overexpression of tetrahydrocannabinolic acid synthase; b: Word cloud in bat from global journal references

\section{Discussion}

There is great interest in the development of cannabinoidbased drugs for the treatment of medical conditions such as $\Delta$-9-tetrahydrocannabinol (THC), cannabidiol for epilepsy [36] [37], cannabigerol for inflammatory bowel disease [38], and tetrahydrocannabivarin as an antiinflammatory [39]. The prospects for commercializing cannabinoids as therapeutics appear to be bright. Several biotechnology companies are emerging to commercialize cannabis-based products to meet the need and to explore the potential of compounding new cannabinoid-like derivatives as therapeutics.

This study was carried out on the one hand, to review previous work concerning the production of recombinant THCAS and on the other hand, to compare the tetrahydrocannabinolic acid synthase gene isolated from the resin of Moroccan Cannabis Sativa (JQ437481. 1) corresponds to 1635 nucleotides with the Cannabis Sativa mRNA precursor of tetrahydrocannabinolic acid synthase (AB057805.1) corresponds to 1885 nucleotides. This study is a first step towards the molecular cloning and expression of the recombinant THCAS enzyme.

The expression levels of THCAS provided direct evidence for the possibility of producing a functional recombinant enzyme and demonstrated that the valuable metabolite THCA can be synthesized in a host other than the plant. First, the E. coli bacterium was not a suitable host for this enzyme. This is due to the absence of posttranslational modifications in prokaryotes. Functional expression of THCAS requires the eukaryotic chaperone protein which is responsible for the correct molecular folding of THCAS and facilitates the covalent binding of FAD to THCAS. Also, THCAS is a glycosylated protein, and has disulfide ponds. These characteristics cannot be achieved in bacteria. Secondly, hairy roots do not secrete THCA synthase, about half of the THCA produced was in the culture medium (Table 1), which is explained by CBGA absorption and THCA liberation regarding tobacco cells. These results demonstrated that THCAS can control THCA production not only in C. Sativa but also in other plants like tobacco [33].

However, the conversion rate of CBGA to THCA in tobacco hairy root cultures was limited to $8.2 \%$ [40]. Thus, the tobacco hairy root expression system revealed a low rate of THCA synthesis [41] and insect cell culture requires expensive complex medium and delicate infection and viral amplification procedures, so a more practical alternative expression system was desired [31]. The first attempt to produce THCA in methylotrophic yeast showed promising results using a Pichia pastoris expression system.

Transgenic P. pastoris cells overexpressing THCAS secreted most of the enzyme into the culture medium. This suggests that most of the enzyme was secreted by the Pichia cells. Several modifications were made for better expression efficiency. Indeed, the addition of the CBGA precursor to the culture medium resulted in only a $10 \%$ bioconversion to THCA. Suspecting that the low conversion rate was the result of the activity of other enzymes metabolizing cannabinoids produced by $\mathrm{P}$. pastoris. Therefore, the Pichia culture supernatant, fed with CBGA, gave the conversion rate of $98 \%$. However, the low solubility of the CBGA precursor in the culture medium limited the amount of THCA produced. Despite this, THCA biosynthesis using this cell-free system was much higher than that of tobacco hairy roots and insect cells. The addition of CBGA to the P. pastoris culture medium resulted in immediate uptake of the precursor by the cells and a high rate of bioconversion to THCA, which remained integrated into the yeast cell membrane. The highest intracellular activity of THCAS $(98 \pm 5$ pkat ml1) was obtained at $15^{\circ} \mathrm{C}$ during $192 \mathrm{~h}$ of culture. THCAS activity was also found in the culture supernatant $(44 \pm 4$ pkat ml-1), which could be due to misorientation in the secretory vesicles upon overexpression[42]. Therefore, the pichiapink yeast was chosen for the optimization study. In addition, recombinant THCAS purified from $P$. 
pastoris had a much higher activity level than native THCAS purified from C. sativa and recombinant THCAS produced by insect cells [33][21].

By using this whole-cell bioconversion system, Zirpel et al. (2015) achieved an exponential increase in THCAS activity levels compared to the cell-free system described by Taura et al. (2007). In fact, the THCA yield was 32.6 mg 1-1 of medium, which is much higher than that obtained by bioconversion using transgenic tobacco root cultures. Indeed, the BMMY medium (for one liter: $10 \mathrm{~g}$ yeast extract, $20 \mathrm{~g}$ peptone, $13.4 \mathrm{~g}$ yeast nitrogen base, 0.4 $\mathrm{mg}$ biotin, and in $100 \mathrm{mM}$ potassium phosphate $\mathrm{pH} 6$ containing $1 \%$ methanol) is optimized such that cultivation takes place in an ordinary Erlenmeyer flask and in a buffered solution at a $\mathrm{pH}$ of 5.5 , with a concentration of $100 \mathrm{mM}$ sodium citrate, at a low temperature $\left(20^{\circ} \mathrm{C}\right)$ and a very gentle rotation $(90 \mathrm{rpm})$. The addition of $0.5 \%$ casamino acids, which are often used as non-selective proteinase inhibitors [20][43], greatly improved the expression level of THCA synthase. In addition, a mixture of proteinase inhibitors containing 4-(2-aminoethyl) benzensulfonyl fluoride, pepstatin A and E-64 was also effective. In addition, the addition of riboflavin, a precursor to $\mathrm{FAD}$, was more effective than FAD [42].

Knowing that the sequence size of the THCAS gene signal peptide is 28 aa. [33], the size of the THCAS gene is 1635 nucleotides, the THCAS gene of Moroccan origin was sequenced with the GenBank accession number (JQ437481-JQ437488) [32]. On the other hand, the alignment between the THCAS gene sequence (GenBank accession number: JQ437481.1) and its mRNA precursor (GenBank accession number: AB057805) was performed. Consequently, the THCAS gene of the Moroccan cannabis variety is also a gene that allows an open reading frame of 1635 nucleotides, encoding a polypeptide of 545 amino acids. This result is essential for further applications such as recombinant enzyme expression. However, the sequencing and molecular cloning step is essential for confirmation.

The structure of THCA synthase is identified as a monomeric enzyme. It consists of two domains (domains I and II) divided by the FAD. In addition, there are two subdomains (subdomains Ia and Ib). Subdomain Ia includes the region from position 28 to $134 \mathrm{aa}$. Subdomain $\mathrm{Ib}$ includes both regions from position 135 to 253 aa and from position 476 to 545 aa. Domain II is an adjacent region including positions 254 to 475 aa [34]. The formation of the oxidative cyclization reaction is likely to occur through an intermediate formed by the removal of hydrogen and proton from the $\mathrm{C} 3$ and $\mathrm{O}^{\prime}$ positions of CBGA. To give two new chemical bonds between $\mathrm{C} 3$ and $\mathrm{C} 4$ and between $\mathrm{O} 6$ ' and $\mathrm{C} 8$ in THCA, respectively [35]. In effect, the THCA synthase-catalyzed reaction involves the transfer of a hydrogen from the $\mathrm{C} 3$ position of CBGA by $\mathrm{FAD}$ with the removal of a proton from the hydroxyl group at the O6' position of CBGA by Tyr484 of the THCA synthase. The latter will provide suitable circumstances for the $\mathrm{C} 4$ and $\mathrm{C} 8$ of the monoterpene moiety of CBGA to approach $\mathrm{C} 3$ and $\mathrm{O} 6$ ' respectively and then produce the new THCA cycle. Furthermore, a catalytic mechanism for the oxidation of CBGA to THCA has been proposed, including the formation of $\mathrm{H} 2 \mathrm{O} 2$ for the regeneration of FAD during catalysis (Figure 5).In addition, a crystal structure of the THCAS enzyme indicates covalent binding of FAD ( linked to His114 and Cys176), disulfide bonding (between Cys37 and Cys99), and six N-glycosylation sites [34]. Along the entire length of the THCAS enzyme protein, there are the positions that interact with the CBGA substrate or the FAD cofactor. This gives way to the need for molecular cloning of the entire nucleotide sequence, as has been done previously [33] [43][44]. In addition, to achieve higher enzymatic activity of the recombinant enzyme. Treatment with endoglycosidase resulted in a deglycosylated THCA synthase with higher catalytic activity than the glycosylated form of the native enzyme or the recombinant enzyme [45].

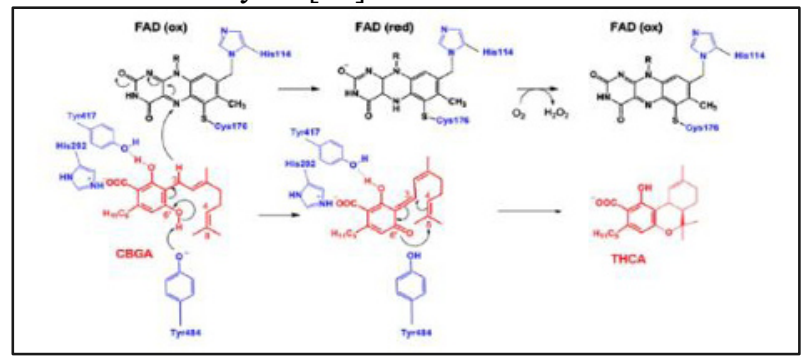

Fig. 5 Proposed catalytic mechanism of THCA synthesis from CBGA. Residues colored blue are from THCA synthase. FAD is colored black, and the substrate (CBGA) and product (THCA) are colored red [46]

The presence of critical sites for THCAS enzymatic activity at the same positions described [46] suggests active expression of the protein at the selected host Pichia pastori. The THCAS gene of the Moroccan variety is a polypeptide-encoding gene of 545 amino acids. The first 28 amino acids constitute the signal peptide. Thus, the length of the predicted mature THCAS polypeptide is 517 amino acids. However, the deduced NH2-terminal shows a considerable difference. The cloning phase is agreed and remains essential.

\section{Conclusion:}

Cannabis has long been "demonized" because it was considered only as a recreational drug, in the pejorative sense of the term. This phenomenon has long slowed down research and blocked access to cannabis as a drug. This is changing as several drugs derived from cannabis are now on the market and some countries are permitting access to natural cannabis for therapeutic purposes. In future, whole yeast cells could provide an alternative method for the production of pharmaceutical THC. Our examinations show a high similarity between the THCAS gene of the Moroccan drug-type cannabis and the cDNA of the same gene. These results are essential for the successful molecular cloning and expression of the recombinant enzyme in Morocco in a eukaryotic host such as the yeast Pichia pasteris. The future of Moroccan cannabis growers is difficult to predict at this stage, but law enforcement and medical legalization processes will certainly influence Moroccan polities. 


\section{References}

1. D. Harper, Online Etymologi Dict (2020)

2. S. Hancock and W. Mckim, Drugs and Behavior An Introduction to Behavioral Pharmacology, 4th ed. (pearson, Upper Saddle River, 2000)

3. H.-L. Li, Econ. Bot. 28, 437 (1974)

4. R. Mechoulam, Cannabinoids As Therapeutic Agents, 1st ed. (Chapman and Hall/CRC, 1986)

5. W. B. O’Shaugnessy, Trans. Med. Phys. Soc. Bengal 421 (1838)

6. D. Baker, G. Pryce, G. Giovannoni, and A. J. Thompson, Lancet Neurol. 2, 291 (2003)

7. P. Robson, Br. J. Psychiatry 178, 107 (2001)

8. L. Iversen, The Science of Marijuana (Oxford University Press, 2018)

9. M. Ben amar, J. Ethnopharmacol. 105, 1 (2006)

10. M. Yassin, R. Haluza-Delay, M. Kadiri, A. El Ouahrani, J. Molero Mesa, and A. Merzouki, J. Ethn. Subst. Abuse. (2017)

11. UNODC, MAROC ENQUETTE SUR LE CANNABIS 2003 (2003)

12. A. Labrousse and L. Romero, Rapport Sur La Situation Du Cannabis Dans Le Rif Marocain (Juin-Août 2001) (2001)

13. G. G. Nahas, P. Zeidenberg, and C. Lefebure, Int. J. Addict. 10, 977 (1975)

14. P.-A. Chouvy and K. Afsahi, Int. J. Drug Policy 25, 416 (2014)

15. P.-A. Chouvy and J. Macfarlane, Int. J. Drug Policy 58, 85 (2018)

16. C. E. Turner, M. A. Elsohly, and E. G. Boeren, J. Nat. Prod. 43, 169 (1980)

17. V. Gaoni and R. Mechoulam, J. Am. Chem. Soc. 86, 1946 (1964)

18. T. Yamauchi, Y. Shoyama, H. Aramaki, T. Azuma, and I. Nishiyoka, Chem Pharm Bull 15, 1075 (1967)

19. M. Kimura and K. Okamoto, Exp. Basel 26, 819 (1970)

20. F. Taura, S. Morimoto, Y. Shoyama, and R. Mechoulam, J. Am. Chem. Soc. 117, 9766 (1995)

21. F. Taura, S. Morimoto, and Y. Shoyama, J. Biol. Chem. 271, 17411 (1996)

22. Y. Shoyama, M. Yagi, I. Nishioka, and T. Yamauch, Phytochemistry 14, 2189 (1974)

23. M. A. El Alaoui, M. Melloul, S. Alaoui Amine, H. Stambouli, A. El Bouri, A. Soulaymani, and E. El Fahime, PloS One 8, e74714 (2013)

24. M. Guzman, Nat. Rev. Cancer 3, (2003)

25. D. Baker, Pryce, G., Giovannoni, G., and Thompson, A. J., Lancet Neurol 2, 291 (2003)

26. E. A. Carlini, Toxicon 44, 461 (2004)

27. R. G. Pertwee, Br. J. Pharmacol. 147, S163 (2006)

28. R. Mechoulam, Science 168, 1159 (1970)

29. R. Mechoulam, Curr Pharma Des 6, 1313 (2000)

30. B. M. Trost and K. Dogra, Org. Lett. 9, 861 (2007)

31. F. Taura, E. Dono, S. Sirikantaramas, K. Yoshimura, Y. Shoyama, and S. Morimoto, Biochem. Biophys. Res. Commun. 361, 675 (2007)
32. M. A. El Alaoui, M. Melloul, S. Alaoui Amine, H. Stambouli, A. El Bouri, A. Soulaymani, and E. El Fahime, PLoS ONE 8, e74714 (2013)

33. S. Sirikantaramas, S. Morimoto, Y. Shoyama, Y. Ishikawa, Y. Wada, Y. Shoyama, and F. Taura, J. Biol. Chem. 279, 39767 (2004)

34. Yoshinari Shoyama, (2012)

35. Futoshi Taura, Satoshi Morimoto, and Yukihiro Shoyama, 117, 9766 (1995)

36. N. A. Jones, S. E. Glyn, S. Akiyama, T. D. M. Hill, A. J. Hill, S. E. Weston, M. D. A. Burnett, Y. Yamasaki, G. J. Stephens, B. J. Whalley, and C. M. Williams, Seizure 21, 344 (2012)

37. O. Devinsky, M. R. Cilio, H. Cross, J. FernandezRuiz, J. French, C. Hill, R. Katz, V. Di Marzo, D. Jutras-Aswad, W. G. Notcutt, J. Martinez-Orgado, P. J. Robson, B. G. Rohrback, E. Thiele, B. Whalley, and D. Friedman, Epilepsia 55, 791 (2014)

38. F. Borrelli, I. Fasolino, B. Romano, R. Capasso, F. Maiello, D. Coppola, P. Orlando, G. Battista, E. Pagano, V. Di Marzo, and A. A. Izzo, Biochem. Pharmacol. 85, 1306 (2013)

39. D. Bolognini, B. Costa, S. Maione, F. Comelli, P. Marini, V. Di Marzo, D. Parolaro, R. A. Ross, L. A. Gauson, M. G. Cascio, and R. G. Pertwee, Br. J. Pharmacol. 160, 677 (2010)

40. F. Taura, S. Tanaka, C. Taguchi, T. Fukamizu, H. Tanaka, Y. Shoyama, and S. Morimoto, FEBS Lett. 583, 2061 (2009)

41. F. Taura, S. Tanaka, C. Taguchi, T. Fukamizu, H. Tanaka, Y. Shoyama, and S. Morimoto, FEBS Lett. 583, 2061 (2009)

42. B. Zirpel, F. Stehle, and O. Kayser, Biotechnol Lett 37, 1869 (2015)

43. F. Taura, E. Dono, S. Sirikantaramas, K. Yoshimura, Y. Shoyama, and S. Morimoto, Biochem. Biophys. Res. Commun. 361, 675 (2007)

44. B. Zirpel, F. Stehle, and O. Kayser, Biotechnol. Lett. 37, 1869 (2015)

45. taura, (2007)

46. Y. Shoyama, T. Tamada, K. Kurihara, A. Takeuchi, F. Taura, S. Arai, M. Blaber, Y. Shoyama, S. Morimoto, and R. Kuroki, J. Mol. Biol. 423, 96 (2012) 